\title{
ŠROTOVNÉ V KONTEXTU MODELOVÁNÍ POPTÁVKY PO AUTOMOBILECH
}

\author{
Marek Litzman, Luděk Kouba, Jitka Dušková
}

\section{Klíčová slova}

šrotovné, modelování poptávky, ekonomická krize

\section{Key Words}

scrappage scheme, demand modelling, economic crisis

\begin{abstract}
Abstrakt
Jedním ze symbolů stimulace agregátní poptávky v průběhu světové hospodářské krize 2008 až 2009 se stalo tzv. šrotovné. Cílem tohoto příspěvku je doporučit rovnici využívající dostupných dat $\mathrm{k}$ odhadnutí efektivity šrotovací prémie. Úvodem je připomenuta historie implementace prémií za šrotování vozidla (již od 70. let 20. století) a jsou představeny významné prŕíspěvky hodnotící tyto minulé programy. Přehled důležitých textů na téma modelování poptávky po automobilech představuje podklad pro návrh rovnice poptávky po automobilech zahrnující šrotovné. Navržená rovnice obsahuje čtyři nezávislé proměnné: disponibilní př́jem domácností, index cen automobilů, index cen základního komplementu, tedy paliva, a dummy proměnnou zachycující případné zavedení šrotovného.
\end{abstract}

\begin{abstract}
The scrappage scheme became one of the most discussed instruments within the aggregate demand stimulation during the world economic crisis 2008-2009. The aim of this paper is to suggest an equation using the available data to estimate the efficiency of the scrappage premium. The initial part of the paper introduces the history of the scrappage premium (since 1970s) and also important papers dealing with the previous schemes. The survey of significant texts focusing on the demand modelling is a base for our suggestion of the automobile demand equation. The suggested equation contents four independent variables: disposable income, car price index, price index of the basic complement (which means fuel) and a dummy variable recording a (non)implementation of the scrappage scheme.
\end{abstract}

\section{Úvod}

Ekonomická krize, která postihla většinu vyspělých zemí světa v letech 2008 a 2009, znovuoživila diskusi na tradiční téma - na kolik má stát v časech hospodářského poklesu intervenovat? Mají vlády povzbuzovat ekonomiku za pomoci nástrojů expanzivní hospodářské politiky či mají v souladu s liberálními doporučeními zachovávat zdrženlivost a pokusit se nezatížit zemi do budoucna neúměrným nárůstem veřejného dluhu?

Jedním z nejvíce diskutovaných symbolů stimulace agregátní poptávky v časech globální hospodářské krize se stalo tzv. šrotovné - tedy prémie na nový automobil za předpokladu ekologické likvidace staršího. Stoupenci opatření zdůrazňovali zejména finanční efektivitu opatření a jeho rozpočtovou neutrálnost díky zvýšení výběru daně, nutnost zlepšení ekologických parametrů a bezpečnosti provozu a zejména závislost tuzemské ekonomiky na automobilovém průmyslu. Odpůrci naopak argumentovali, že zvýšený výběr daně je ve skutečnosti nereálný, protože vygenerovaná poptávka, která by v období bez dotace nevznikla, bude minimální. Šrotovné tak má být podle odpůrců pouze selektivní pobídkou 
automobilového průmyslu (získanou v důsledku silné automobilové lobby), na úkor ostatních odvětví ekonomiky.

Málo známou skutečností přitom je, že obdobné programy byly příležitostně zaváděny již od 70. let minulého století, v hojnější míre pak zejména v letech devadesátých. Bývalé Československo dnes patří mezi evropská centra automobilového průmyslu, jenž se, at' již př́imo či neprrímo, významně podílí na tvorbě českého i slovenského HDP. Nabízí se tedy podívat se na problematiku šrotovného v kontextu formování poptávky na trhu s automobily.

Hlavním cílem tohoto př́spěvku je doporučit rovnici využívající dostupných dat k odhadnutí efektivity šrotovací prémie. V první části textu je připomenuta historie prémií za šrotování vozidla a představeny významné práce hodnotící tyto minulé programy. Přehled významných prací na téma modelování poptávky po automobilech představuje podklad pro náš návrh rovnice, který je obsažen ve třetí části př́íspěvku.

\section{Zavádění šrotovného - motivace a účinnost}

Přestože princip šrotovného vešel ve všeobecnou známost až v souvislosti se světovou ekonomickou krizí let 2008 až 2009, není jeho princip ničím novým. Globálně řečeno, jde o nástroj stimulace poptávky pomocí státní finanční podpory, jaký známe i v mnoha jiných podobách.

Šrotovné v podobě, jakou jsme poznali $v$ uplynulých třech letech, je taktéž již déle používaným instrumentem. Pravděpodobně poprvé bylo zavedeno ve Švédsku v roce 1975 (Cassels, 2005). Účelem bonifikace bylo motivovat majitele, aby nenechávali svá stará auta odstavená na veřejných parkovacích plochách či v přírodě, ale aby je nechali ekologicky zlikvidovat. Počáteční úspěch programu postupně odezníval a v roce 1988 tak bylo rozhodnuto o navýšení prémie z 300 SEK na 500 SEK, další navýšení na 700 švédských korun proběhlo $v$ roce 2001. Z dnešního hlediska je zajímavější druhá prémie zavedená ve Švédsku v roce 1992 a vyplácená majitelům provozuschopných vozidel. Jejím účelem již bylo podpořit rychlejší obměnu vozidel za účelem ekologizace provozu. Výše podpory byla stanovena na 1500 SEK a v roce 2001 byla zavedena její diferenciace dle věku vozidla.

Mnohé státy v průběhu posledních dvou dekád zaváděly různé formy šrotovného. Lišily se výší podpory, podmínkami udělení i dobou trvání. Často odkazovaným programem jsou španělské projekty Obnova. Dle práce, jejímiž autory jsou Licardo a Sampayo (2006), šlo o dvojici navazujících dočasných programů na podporu obnovy vozového parku z let 1994 a 1995. Po jejich skončení byl v roce 1997 započat podobný, časově neomezený projekt. Hlavním cílem bylo zvýšit bezpečnost vozů na silnicích a redukovat emise škodlivých plynů; nicméně v tomto případě již byla sledována rovněž podpora výroby a prodejů nových vozů.

Podobný program byl zaveden také ve Francii. Adda a Copper (1997) zkoumají dvojici programů, které byly zavedeny v roce 1994, resp. 1995. Prémie 5-7 tisíc franků byla $\mathrm{k}$ dispozici majitelům desetiletých a později i osmiletých vozů.

Také v USA byl na počátku 90. let za vlády prezidenta George Bushe staršího zaveden program oficiálně nazvaný Car Allowance Rebate System (CARS), častěji známý pod označením „Cash for clunkers“. Jeho primárním cílem bylo očistit města od vozidel s vysokými emisemi. (Hahn, 1995) 
Za pozornost stojí proklamovaný účel zavedených opatření, kterým byla opět zejména ekologie provozu a jeho bezpečnost, nikoliv stimulace nedostatečné agregátní poptávky. Ten spatřujeme až při realizaci opatření v průběhu světové hospodářské krize v letech 2008 až 2009. Např́klad i důvodová zpráva tuzemského zákona ukotvujícího zavedení šrotovného staví na první místo podporu automobilového průmyslu a až na druhé ekologizaci vozového parku (PSP, 2009).

Přestože ekonomický dopad nebyl primárním cílem dřívějších programů, byl v některých pracích zkoumán. Nejčastěji citovanou prací je v tomto případě Hahnův článek z roku 1995. Studie je reakcí na výše zmíněný program „Cash for clunkers“ a zabývá se ekonomickým vyčíslením ekologických úspor. Zajímá se proto o náklady na šrotaci a srovnává je se snížením ekologické zátěže $\mathrm{z}$ emisí při různých úrovních šrotování a ekonomických hodnotách znečištění.

Pro svůj výzkum Hahn zvolil Los Angeles, a to z důvodu vysoké míry tamních problémů s emisemi. Hahn tvrdí, že pokud se šrotování ukáže z ekologicko-ekonomického hlediska neefektivní tam, je vysoce nepravděpodobné, že by jinde v USA efektivní bylo. Vyvozuje přitom závěr, že není jednoznačně možné říci, zda je šrotování vozů z ekologických důvodů ekonomicky efektivní. Jako jeden z důvodů uvádí, že velmi záleží na hodnotě, kterou přidá konkrétní ekologické úspoře ten, kdo o realizaci opatření rozhoduje, protože ekonomická kvantifikace je přirozeně problematická. Podle Hahna je největší potenciál tohoto opatření v silně znečištěných lokalitách, kde se pohybuje větší množství starších vozů. Potom jsou i mezní zisky z tohoto programu vysoké.

Sandström (2003) upozorňuje na vedlejší efekty šrotovacích akcí. Nárazový růst šrotu na trhu může ostře měnit ceny šrotového železa a dalších druhotných materiálů vytěžitelných z vraků. Uvádí, že během zkoumaného úseku švédského šrotovného na trhu vznikl dokonce nadbytek šrotu, díky čemuž klesla jeho cena do záporných hodnot. Z ekologického hlediska má podle něj takováto akce smysl jen tehdy, je-li vývoj ekologických technologií dostatečně rychlý. Za př́íklad dává zavádění katalyzátorů.

Již výše zmíněný plán obnovy španělského automobilového parku se stal objektem zájmu studie, jejímiž autory jsou Licandro a Sampayo (2005). Přestože i v tomto případě bylo motivací zejména zmodernizování vozového parku z hlediska ekologického a bezpečnostního, autoři studie se zabývali ekonomickými dopady španělského šrotovného z druhé poloviny 90. let, zejména změnou prodejů a změnou stáŕí vozového parku. Autorská dvojice dospěla modelováním trhu a srovnáváním s empirickými zjištěními $\mathrm{k}$ názoru, že šrotovné může přispívat ke zlepšení prodejů vozů v krátkém období, navýšení prodejů z hlediska delšího období je ale zanedbatelné. Také snížení průměrného věku vozového parku je poměrně malé.

Vrat'me se nyní do nedávné minulosti. Jak je patrné ze srovnání, které vypracovala Evropská asociace automobilových výrobců (ACEA, 2009a, resp. ACEA, 2009b), vlna šrotovacích prémií reagujících na nadcházející recesi byla zahájena na přelomu let 2008 a 2009. Již v prosinci 2008 byly programy spuštěny ve Španělsku a Francii, důležité německé a italské trhy následovaly v lednu resp. v únoru 2009. Na základě uvedených srovnání můžeme tvrdit, že obvyklá výše prémie činila 1000 až 1500 euro, vozidlo obvykle muselo být starší deseti let a státy stanovovaly jistá ekologická kritéria. Obvykle šlo o splnění emisní normy nebo jistých maximálních emisí oxidu uhličitého ${ }^{1}$.

1 Oxid uhličitý není takzvanými Euro normami regulován. Z technického hlediska jde spolu s vodou o čistou emisi, která je závislá jen na spotřebě vozu a použitém palivu, nikoliv na nedokonalostech spalování jako ostatní 
Také v ČR byla možnost šrotovného formálně právně ukotvena a to jako součást zákona o podpoře hospodářského růstu, který včlenil nový $\$ 37 d$ do zákona o odpadech (zák. č. 185/2001 Sb.). Podle zákona měl možnost získat příspěvek ve výši 30 tisíc korun každý, kdo zakoupí nový automobil v ceně do 500 tisíc korun, přičemž jeho emise CO2 nesměly překročit $160 \mathrm{~g} / \mathrm{km}$ a musel být splněn emisní limit EURO IV. Zákon stanovil, že podrobnosti programu, mezi kterými se nachází i datum spuštění programu, určí vláda svým nařízením. Vláda však o započetí programu nikdy nerozhodla. Zákon ale nebyl legislativně zrušen, prakticky je tak možné se k němu kdykoliv vrátit.

Šrotovné zaváděné $\mathrm{v}$ nedávných letech zatím nebylo, vzhledem k nedlouhému odstupu, v odborných žurnálech ve větší míře hodnoceno. Přesto lze citovat práci, jejímiž autory jsou Mian a Sufi (2010). Autoři se zabývali srovnáváním vybraných ekonomických ukazatelů ve městech, kde s výrazným zastoupením automobilového průmyslu s městy, kterým se toto odvětví naopak vyhýbá. Přestože ekonomická teorie může předpokládat jistou substituci a zvýšené prodeje vozidel by mohly ústit ve sníženou poptávku po jiných průmyslových výrobcích, autoři nezjistili zaznamenatelný dopad na místa zaměřující se na jiný než automobilový průmysl. Na druhou stranu, značný pozitivní vývoj nenastal ani v místech s vysokým podílem automobilového průmyslu, nastalo jen jisté zpomalení negativních jevů po dobu dotace, po jejím skončení však nastal ještě zásadnější pád. Obecně nenastolilo americké šrotovné žádný strukturální zlom ani v jedné ze sledovaných skupin měst, konstatují autoři.

Autoři Li, Linn a Spiller (2010) vypočítali, že americký program CARS vytvořil v krátkém období 3676 pracovních míst, v dlouhém období 2050 míst a to přímo v automobilovém průmyslu. Oproti tomu Copper, Chan a McAlinden (2010) odhadují, že bez programu by v celém hospodářství včetně všech navazujících odvětví bylo bez práce 40200 občanů USA. Obě zmíněné studie hodnotí program spíše pozitivně.

\section{Teoretický kontext modelování poptávky po automobilech}

Problematikou modelování poptávky po automobilech se začali ekonomové zabývat ve 30. letech minulého století, v době, kdy začínaly být automobily důležitým obchodním artiklem, který ovlivňuje ekonomiku státu. Mimo to je předpovídání růstu počtu automobilů důležité jak pro plánování dopravní infrastruktury, tak i pro samotné výrobce.

Jeden z prvních modelů představil Wolff (1938). Jeho článek uveřejněný v prestižním žurnálu Econometrica $^{2}$ ukazuje na souvislosti mezi počtem sešrotovaných a nových vozů. Popisuje, že produkt, $v$ tomto př́ípadě automobil, má jistou průměrnou životnost, přičemž po uplynutí této životnosti je starý vůz nahrazen novým. Šrotování vozů a nákup náhrady má tak zpoždění $\mathrm{T}$ za hodnotou nákupu nových vozů v určitém roce. Autor rozděluje počet nákupů nových vozů jako součet poptávky po náhradě sešrotovaných vozů, které ztotožňuje s počtem sešrotovaných vozů v konkrétním období, a poptávky po prvním nákupu vozu. Druhá proměnná přitom nemusí být nutně kladná. Wolff to demonstruje na příkladu let Velké deprese, kdy počet šrotovaných vozů převážil počet nových nákupů.

emise, např́iklad oxidů dusíku či oxidu uhelnatého. Limitem emisí oxidu uhličitého je de facto regulována maximální spotřeba vozu. Více viz např́íklad Europan Comission (2010).

2 Překlad z originálu De vraag naar personenauto's in de Vereengde Staten, publikovaného v roce 1936 $\mathrm{v}$ časopise De Nederlandsche Conjunctuur 
Podobný způsob používají v moderní studii i Greenspan a Cohen (1996). Sestavují rovnici, podle které se prodeje vozů rovnají součtu tří proměnných. První je rozdíl velikostí trhu, tedy rozdíl počtu existujících vozidel na konci dvou po sobě jdoucích období. Druhou je technologická šrotace, kterou autoři rozumí zejména reálnou životnost konkrétních vozů, která je často vlastní přímo konkrétnímu vyrobenému kusu již z výroby ${ }^{3}$. Tuto proměnnou není možné chápat cyklicky, protože u každého vyrobeného kusu roste pravděpodobnost šrotace nelineárně s věkem. Poslední proměnnou je cyklická šrotace. V této proměnné jsou skryty důvody, které nutí spotřebitele k odložení vozu, které se na rozdíl od předchozích proměnných neváží přímo k původnímu automobilu. Jde o cenu nových vozů, cenu paliva a nákladů na údržbu vozu. Autoři dokazují, že tato složka je cyklická a pohybuje se inverzně vůči poměru ceny nových vozů a cen oprav vozidel.

Za zmínku stojí také práce z šedesátých let, jejímž autorem je Walker (1968). Autor zkoumá hlavní determinanty, které určují přirozenou míru šrotování vozidel. Matematicky zjišt'uje, že nejdůležitější proměnnou, podle které se majitel rozhoduje, zda odstaví svůj vůz, je stáří vozu, další podstatné parametry můžeme hledat v cenách oprav a údržby, stavu vozu a očekávané prodejní ceně vozidla.

K podobnému závěru dochází také Parks (1977); i on označuje za nejdůležitější proměnnou, jež určuje pravděpodobnost, že vůz bude v konkrétním roce sešrotován, věk vozu. Za významnou považuje cenu oprav, ale také proměnnou zahrnující spolehlivost vozu z výroby.

Autoři ve svých literárních přehledech často dělí modely dle použití agregovaných a neagregovaných dat, napřr. Train (1996); Whelan (2007). Podle Whelana se starší práce zaměřují spíše na agregátní modely, které zobrazují celonárodní nebo alespoň regionální vývoj. Novější tendence je zaměřovat se spíše na neagregovaná data sledující socioekonomický vývoj, dostupnost alternativních druhů dopravy a místní charakteristiky. Agregátní modely podle Traina (1996) počítají s faktem, že agregátní poptávková funkce je prostým součtem individuálních poptávkových funkcí všech jedinců v regionu.

Novější literární přehledy, zejména De Jong, Fox, Peiters, Daly a Smith (2004), dělí modely do více skupin, konkrétně výše zmíněný do desíti. Modely rozlišuje podle různých parametrů, např́íklad použití dat poptávky a/nebo nabídky, agregace, dynamiky nebo statiky modelu, základu v ekonomické teorii, speciálního výpočtu pro fleetové ${ }^{4}$ vozy, možnosti použití pro odlišné skupiny vozů apod.

Pro účel výběru rovnice pro simulaci trhu s automobily se nabízí model, jehož autorem je Carlson (1978). Poptávka po automobilech v USA v období 1965-1975 je zde rozdělena do jednotlivých obchodních tříd. Autor na modelu staví i nadále, o dva roky později vychází článek, ve kterém je model využit pro předpovídání trhu (Carlson, Umble, 1980). Pro svoji předpověd' autoři užívají rovnici:

3 Pod spolehlivostí můžeme vidět více faktorů, přičemž část z nich je dána kvalitou výroby, část z nich chováním majitele k vozu, kvalitou oprav apod.

4 Též flotilový prodej. Rozumí se jím prodej většího množství vozů, tedy flotily, jednomu odběrateli, obvykle firmě. 


$$
D_{t}^{i}=B_{0}+B_{1} Y_{t}^{D}+B_{2} P_{t}^{i}+B_{3} G_{t}+E_{t}
$$

kde $D_{t}$ je velikost poptávky v čase $t, B_{0}-B_{3}$ jsou koeficienty rovnice, $Y_{t}^{D}$ je disponibilní př́ijem $\mathrm{v}$ čase $t, P_{t}$ je cena aut $\mathrm{v}$ čase $t, G_{t}$ značí cenu benzínu v čase $t$ a $E_{t}$ je náhodný člen. Koeficienty $i$ značí třídu vozu, model totiž počítá se samostatnými vzorci pro jednotlivé třídy. Původní rovnice zahrnovala také proměnnou Stock, což můžeme přeložit jako velikost trhu. Autor tuto proměnnou počítá z velikosti poptávky po automobilech, míry šrotování aut a velikosti trhu $\mathrm{v}$ minulém období, ovšem při výpočtech se ukázala být statisticky nevýznamná a $\mathrm{v}$ pozdějším modelu již použita není.

Pro potřeby sledování trhu v poměrně dlouhém období očišt'ují autoři poptávku po vozidlech o vliv počtu obyvatel, aby nebylo nutné zanášet do modelu další proměnnou. V prvním př́ípadě jsou celkové prodeje vozidel děleny počtem obyvatel a je tak získána hodnota poptávky per capita, ve druhém případě jsou hodnoty očištěny o sezónní vliv a vliv počtu obyvatel.

Jednoduchým statickým modelem, lineárním v parametrech, a s použitím kvartálních dat Carlson (1978) dokazuje, že nejdůležitějším faktorem, který působí na poptávku po vozech, je disponibilní př́jem per capita. Vysvětluje také, že tato skutečnost není nijak překvapivá, nebot' nákupy zboží dlouhodobé spotřeby jsou podle ekonomické teorie obvykle ovlivněny v největší míře právě př́ijmem. Nikterak nepřekvapí ani vysoká statistická relevance ceny vozidel ve tř́ídě.

K podobným závěrům se kloní také Kobos, Erickson a Drennen (2003). I podle autorů této studie je hlavním determinantem poptávky po automobilech, jakožto typickými zástupci zboží dlouhodobé spotřeby, př́jem obyvatelstva. Je to z toho důvodu, že automobily jsou poměrně drahé, přitom ale nejsou nezbytné, a proto je nutné mít dostatek disponibilních zdrojů na jejich nákup. Autoři studie, která se zabývala poptávkou v Číně, uvádějí, že význam ostatních faktorů, které se netýkají prríjmu, je v rozvíjejících se ekonomikách zanedbatelný.

Účelem modelu, který použili Kobos, Erickson a Drennen, byla simulace růstu trhu s automobily a jejich provozu. Č́st věnovanou objemu prodejů vozů postavili autoři na vzorci, který zahrnuje veličiny disponibilní př́ijem, poptávková elasticita, nasycenost trhu a velikost populace. Ta zde má svoji roli, protože simulace byla konstruována na trricetileté období.

Arguea, Hsiao a Taylor (1994) se mimo jiné zabývají vlivem př́immu na základní charakteristiky vozu - výkon, komfort (reprezentovaný velikostí interiéru) a spotřebu paliva. Ve svých výpočtech používají data z průzkumů mezi kupujícími. Výsledkem je zjištění, že spolu se stoupajícím př́ijmem spotřebitelé preferují více výkonu a více komfortu, naopak spíše jsou ochotni vzdát se nízké spotřeby. To naznačuje, že se stoupajícím příjmem spotřebitelé raději volí vozy vyšších tříd. Tohle zjištění koresponduje s čistě technickými poznatky, vozy vyšších tříd jsou obecně větší a komfortnější. $Z$ velikosti plyne vyšší hmotnost a nutnost silnějšího pohonu. Ten spotřebuje více paliva. Pro výpočet poptávky je autory užit vzorec: 


$$
z_{i t}^{*}=c_{i}+\sum_{j=1}^{n} a_{i j} p_{z_{j t}}+b_{i} y_{t}+n_{i t}
$$

kde $z_{i t}^{*}$ je poptávka na trhu i v čase $t, a_{i j}, b_{i}$ a $c i$ jsou parametry rovnice, $p_{z_{j t}}$ je cena vozu $j \mathrm{v}$ čase $t$ a $y_{t}$ je důchod $\mathrm{v}$ čase $t$.

Whelan (2007) používá pro předpověd’ podoby trhu s automobily do roku 2031 velmi podrobný model, jež zahrnuje množství proměnných, které dále člení. Pro výpočet používá data o př́ijmech domácností, o nichž tvrdí, že jsou obecně považována za nejdůležitější, což potvrzuje předešlé odstavce. Další proměnnou je struktura domácností, které dělí podle počtu členů a jejich dospělosti. Důležitou proměnnou jsou ceny, a to jak ceny kupní, tak i ceny ovlivňující náklady provozu vozidla. Pro modelování trhu autor zkoumá také dostupnost bydliště, kde využívá údaj hustoty osídlení. Pátou proměnnou je dostupnost služebních vozů a pod posledním bodem jsou zahrnuty ostatní relevantní vlivy, tedy naprríklad míra kriminality, dostupnost parkování nebo očekávání budoucích nákladů. Vzorec má tedy tvar:

$$
U=A S C_{1}+b_{1} L P A+\left(c_{1}+c_{h 1} D_{h}+c_{a 1} D_{a}\right) Y+d_{1} E+e_{1} O+f_{1} R
$$

kde $a_{1}-f_{l}$ jsou parametry, $L P A$ je počet řidičských průkazů na dospělého, $Y$ je př́jem domácností, $D_{h}$ je dummy proměnná vektoru struktury domácností, $D_{a}$ je dummy proměnná vektoru dostupnosti bydliště, $O$ symbolizuje ceny nákupu, $R$ značí náklady provozu. Pro př́ípad, že rodiny mají $\mathrm{k}$ dispozici firemní auto, přičítá autor jednu dummy proměnnou za každý takový vůz.

Model, jehož autory jsou Lee a Kang (2008), primárně zkoumá kř́žovou elasticitu $\mathrm{u}$ vybraných proměnných na trhu v Brazílii. Autoři na tamních datech spočítali, že při poklesu úrokových měr o $1 \%$ vzrostou prodeje vozů o $0,32 \%$. Růst HDP o $1 \%$ podle této studie vyústí v růst prodejů o $1,82 \%$. Autoři pro účely výpočtu použili vzorec:

$$
Y_{t}=\beta_{0}+\beta_{1} X_{1 t}+\beta_{2} X_{2 t}+\beta_{3} X_{3 t}+\beta_{4} X_{4 t}+\varepsilon
$$

přičemž $Y_{t}$ značí poptáku po automobilech v čase $t, \beta 0-\beta 4$ jsou parametry rovnice, $X_{1 t}$ je cenový index zboží dlouhodobé spotřeby, $X_{2 t}$ je cena paliv, $X_{3 t}$ je úroková míra a $X_{4 t}$ je HDP. Autoři v modelu použili cenový index zboží dlouhodobé spotřeby namísto cenového indexu aut a HDP namísto disponibilního důchodu z důvodu dostupnosti dat.

\section{Efektivita šrotovného - návrh modelu a jeho proměnné}

Sestavme nyní s pomocí získaných poznatků rovnici využívající dostupná makroekonomická data $k$ odhadu efektivity šrotovného. $Z$ výše uvedeného výběru používaných rovnic je patrné, že nejčastěji jsou použity proměnné zobrazující př́ijem a cenu, kterou můžeme dělit na cenu provozu a cenu pořízení. Užití těchto tří proměnných odpovídá obecné ekonomické teorii, která očekává, že hlavním determinantem poptávky bude právě finanční možnost koupě.

Šrotovací prémie byla $\mathrm{v}$ uplynulých programech poskytována téměř výhradně fyzickým osobám, nikoliv firmám. Z hlediska přesnosti modelu je proto vhodné, je-li to možné, očistit prodeje od dodávek podnikatelským subjektům. 
Lze vznést otázku, je-li nutné při odhadu modelu očišt'ovat data o celkový potenciál trhu, který je dán počtem obyvatel či ještě lépe celkovým počtem řidičů. $O$ počet obyvatel očišt’uje model Carlson (1978), resp. Carlson, Umble (1980). Naopak Whelan (2007) zahrnuje počet řidičských průkazů jako jednu z proměnných rovnice.

Je třeba říci, že všechny zmíněné modely jsou konstruovány pro delší období, řádově v desetiletích. Oproti tomu zkoumané šrotovné je záležitostí obvykle velmi krátkodobou, přičemž $\mathrm{v}$ rozmezí několika let bude velmi pravděpodobně změna $\mathrm{v}$ uvedených proměnných zanedbatelná. Za předpokladu, že v dané situaci v daném státě nebyla zaznamenána zásadní změna v počtu řidičů, je možné takovouto úpravu pro jednoduchost výpočtu zanedbat.

Při modelování poptávky po zboží dlouhodobé spotřeby, například automobilů, je nutné vzít v potaz také z dlouhodobého hlediska nelineární vztah mezi př́ijmem a počtem zakoupených produktů. Jak vychází z ekonomické teorie, resp. jak uvádějí Dargay a Gately (1998), při nízké úrovni prŕjmů se bude počet kupovaných vozidel zvyšovat nejprve pomaleji, s růstem př́ijmů značně zrychlí a zpomalovat opět začne až s blí̌žící se asymptotou na úrovni hranice nasycení trhu. Opsaná křivka může mít tvar blízký Gompertzově funkci. Je však opět nutné vzít v potaz délku opatření a tedy i pravděpodobného zkoumaného úseku. Díky tomu je možné jej na S-křivce považovat za dostatečně krátký na to, aby bylo možné jeho zakřivení zanedbat.

Takto koncipovaná rovnice může mít tvar:

$$
D_{t}=\beta_{0}+\beta_{1} Y_{t}+\beta_{2} C_{t}+\beta_{3} F_{t}+\beta_{4} D_{t}+\varepsilon
$$

přičemž jako $D_{t}$ označujeme poptávku po automobilech v čase $t$, jako $\beta_{0-4}$ jsou označeny parametry, $Y_{t}$ značí př́ijmovou proměnnou v čase $t, C_{t}$ je označením ceny vozidel $\mathrm{v}$ čase $t$, proměnná $F_{t}$ je cenou komplementu v čase $t$ a $D_{t}$ je dummy proměnnou pro šrotovné. Jednotlivé proměnné jsou rozebrány $\mathrm{v}$ následujícím textu.

\section{Příjmová proměnná}

Z ekonomického hlediska je př́ijmová proměnná základním parametrem, který určuje nákupní chování spotřebitele. Při zvyšujícím se přijmu je typický nadproporcionální růst nákupů luxusního zboží, kam lze zařadit i automobily.

Problematika ideální př́ijmové proměnné je diskutována $\mathrm{v}$ mnoha pracích. Naráží na ni např́iklad Whelan (2007) a užívá př́íjem domácností. Tento parametr upravuje koeficienty zahrnujícími místo bydliště a počet osob v domácnosti, aby získal data lépe reflektující způsob života a náklady na něj.

Oproti tomu Kobos, Erickson a Drennen (2003) využívají pro svou předpověd' jednodušší hrubý národní důchod per capita. Autoři Dargay a Gately (1999) užívají disponibilní osobní př́ijem, Tanner (1978) používá př́ijem na hlavu v konstantních cenách.

Uvedené srovnání naznačuje další rozdíl, který mezi pracemi panuje, totiž užití dat $\mathrm{s}$ přihlédnutím nebo bez přihlédnutí k měnící se kupní síle peněz. Často citované práce, jejichž autory jsou Button, Ngoe a Hine (1993) nebo Dargay a Gately (1999), úpravu dle kupní síly nepoužívají. Liší se tím například od autorské trojice Kobos, Erickson, Drennen (2003). 
Ze všech možných vyjádření osobního př́ijmu v tomto příspěvku volíme disponibilní příjem počítaný na hlavu. Jeho základní výhodou je očištění o daně, které snižují př́íjmy domácností a které se mohou zvláště v turbulentním období hospodářské krize měnit. Na druhou stranu je tento parametr také dobře dostupný, což splňuje premisu stanovenou v úvodu příspěvku.

\section{Proměnná cen vozidel}

Cenový index $\mathrm{v}$ tomto vzorci doplňuje př́ijmovou položku. Poměr př́ijmové položky a cenového indexu vozidel ukazuje, zda auta pro kupující relativně, tedy ve vztahu k př́ijmu, zlevnila či zdražila. Kombinace příjmové položky a cenového indexu má zásadní význam pro zjištění dostupnosti vozů z pohledu kupujících.

Cenový index je vhodné aplikovat na rozsah vozů shodný s rozsahem vozů v modelu. Tento postup je použit v řadě prací, viz např́íklad Carlson (1978). Problém může nastat v dostupnosti podobných dat, obecné zdroje jako Eurostat nebo ČSÚ takto podrobnou statistiku nevedou. Harmonizovaný index zahrnuje jen položku Automobily, která je konstruována napříč obchodními trrídami, adekvátní je tedy zejména při pohledu na trh jako celek.

Autoři Lee a Kang (2008) nahrazují tuto položku pouhým indexem cen zboží dlouhodobé spotřeby. Tento postup lze provést v situaci, kdy není dostatečně podrobná položka dostupná, nebot' automobily tvoří podle autorů dostatečně významnou položku tohoto indexu.

\section{Proměnná cen komplementu}

Třetí prvek v rovnici zohledňuje náklady na provoz aut, tedy základní komplement k vozidlu. Příliš vysoké náklady na provoz mohou odradit kupující od koupě vozu, příp. je motivovat ke koupi vozu méně náročného na údržbu a provoz, což má potenciál měnit rozložení nákupů mezi třídami, popřípadě typy vybavenými úspornými technologiemi.

Teoretické přístupy se neshodují v otázce zařazení provozního cenového prvku do rovnice. Některé preferují indexy celkových nákladů na provoz vozidla, (Whelan, 2007) jiné užívají jen nákladů na paliva. (Carlson a Umble, 1980; Lee a Kang, 2008)

Harmonizovaný cenový index zahrnuje do provozních nákladů ceny paliv a dává jim i vysokou váhu, přesto je nutné zvážit vysokou informační nerovnováhu mezi jednotlivými položkami. S cenami paliv je spotřebitel obecně dobře seznámen. Oproti tomu položka nákladů na provoz osobních prostředků obsahuje také položky, jež spotřebitel zjistí jen se značnými obtížemi, například ceny brzdových destiček a jejich výměny, seřízení přední nápravy či výměny blatníku. Právě silně nerovnoměrná informovanost o cenách jednotlivých položek může vyvolat paradoxní situace, kdy například razantní vzestup cen servisních prací v indexu převáží pokles ceny paliv i přes jejich vyšší váhu v koši. Spotřebitel ale přesto spíše nabude pocitu, že ceny provozu vozidla klesají, protože o zdražení v servisech se s vysokou pravděpodobností vůbec nedozví.

Přestože tato proměnná je do modelu obvykle řazena, podle výpočtů (například Ingram a Liu, 1997) nebývá její váha vysoká a podle autorů spíše ovlivňuje chování spotřebitele až následně po nákupu, tedy počet jízd, než nákup samotný, alespoň uvažujeme-li v agregátním vyjádření. 


\section{Dummy proměnná}

Výše popsané proměnné, dle našeho názoru, rozhodující měrou formují křivku prodejů osobních vozů na konkrétním území a v konkrétním čase. Určují tedy obvyklý tvar poptávky po automobilech bez zásadních vnějších vlivů.

Pro simulaci efektu šrotovného, coby významného vnějšího vlivu, je do rovnice přidána dummy proměnná, která může nabývat hodnot 1 a 0 . V období, kdy je na zkoumaném území aplikována šrotovací prémie, nabývá dummy proměnná hodnoty 1 , jinak je rovna nule.

Odhadnutá výše parametru dummy proměnné je průměrným počtem vozidel, které byly v daném období prodány díky prémii nad rámec poptávky, která by vznikla i bez podpory. Vynásobíme-li tedy tuto hodnotu počtem období, ve kterých nabývá dummy proměnná hodnoty 1, získáme odhad celkového počtu vozů, o které byl navýšen celkový počet prodaných vozů po dobu aplikace podpory oproti myšlenému stavu bez podpory.

Právě počet vozů prodaných nad úroveň obvyklé poptávky je základem pro stanovení okamžité efektivity podpory. Srovnáním odhadu s počtem vyplacených prémií je možné odhadnout efektivitu podpory, která by měla být základním klíčem ke stanovení optimálních kroků nositele hospodářské politiky státu. Zjistíme tak, jaké procento podpory šlo na poptávku, která by v daný čas a na daném místě stejně vznikla, a jak velká část putovala na předsun poptávky z budoucích období.

\section{Závěr}

V souvislosti s hloubkou hospodářské krize v letech 2008 až 2009 se šrotovné rychle dostalo do povědomí ekonomů i tvůrců hospodáŕských politik. S ohledem na jeho snadnou implementaci, politickou přitažlivost i zdánlivou fiskální neutralitu se lze domnívat, že v případě opakujících se hospodářských problémů bude toto opatření i v budoucnosti používáno jako operativní nástroj řešení poptávkové krize; zejména se tak může stát u států, kde tvoří automobilový průmysl významný podíl na celkové produkci. Dosavadní práce zkoumající ekonomickou efektivitu šrotovného ovšem přinášejí přinejmenším rozporuplné výsledky. Přeci jen lepší se jeví být mimoekonomické efekty některých programů, zejména v období výrazného zlepšování technologií.

Náš příspěvek dává návod, jak za pomoci obecně dostupných dat, využitím navržené rovnice, odhadovat ekonomickou efektivitu takovéhoto opatření, která by měla být důležitým argumentem pro tvůrce hospodářské politiky, zda toto opatření využít či ne.

Základem je modelace poptávky s využitím tří základních proměnných. První z nich, př́ijem domácností, jsme s ohledem na časté změny zdanění zvolili ve formě disponibilní př́ijem per capita. Na př́ijmovou položku navazuje index cen automobilů, jež je běžně dostupný v rámci Harmonizovaného indexu spotřebitelských cen HICP; a index cen základního komplementu, za který bylo s ohledem na jeho signalizační funkci pro spotřebitele zvoleno palivo. Ve zkoumaném období aplikace hospodářské podpory je nutné přidat dummy proměnnou pro šrotovné (nabývající v prrípadě zavedení tohoto opatření ve sledovaném období hodnoty 1), která je klíčem pro vyčíslení odhadu počtu vozů, jež se ve sledovaném období prodaly nad úroveň poptávky očekávané bez zavedení šrotovného. Srovnáním s počtem vyplacených prémií je možné odhadnout krátkodobou efektivitu prostředků vložených do systému podpory. 


\section{Literatura:}

[1] ACEA. 2009a. Vehicle Scrapping Schemes in the European Union. [Online] [cit. 6. 10 2010.] Dostupné:

<http://www.acea.be/images/uploads/files/20090406_Scrapping_schemes.pdf>.

[2] ACEA. 2009b. Vehicle Scrapping Schemes in the European Union. [Online] [cit. 23.4 2011.] Dostupné:

$<$ http://www.acea.be/images/uploads/files/20101014_Current_Fleet_Renewal_Scheme s.pdf>.

[3] ADDA, J., COPPER, R. Balladurette and Jupette A Discrete Analysis of Scrapping Subsidies. NBER, 1997, Working Paper No. 6048. Dostupné:

$<$ http://eprints.ucl.ac.uk/15019/1/15019.pdf>.

[4] ARGUEA, N. M., HSIAO, C., TAYLOR, G. A. Estimating consumer preferences using market data-an application to US automobile demand. Journal of Applied Econometrics, 1994, Vol. 9, No. 1, pp. 1-18.

[5] BUTTON, K., NGOE, N., HINE, J. Modelling Vehicle Ownership and Use in Low Income Countries. Journal of Transport Economics and Policy, 1993, Vol. 27, No. 1, pp. 51-67.

[6] CARLSON, L, R. Seemingly unrelated regression and the demand for automobiles of different sizes, 1965- 75: A disaggregate approach. Journal of Business, 1978, Vol. 51, No. 2, pp. 243-262

[7] CARLSON, L. R., UMBLE, M. Statistical demand functions for automobiles and their use for forcasting in an energy crisis. Journal of Business, 1980, Vol. 53, No. 2, pp. 193-20.

[8] CASSELS, S. Management of end-of-life vehicles: lessons learned from Europe for the New Zeland situation. WasteMinz Conference Paper, 2005. Dostupné: $<$ www.wasteminz.org.nz/conference/conferencepapers2005/Sue\%20Cassells.pdf>.

[9] COPPER, A., CHAN, Y., MCALINDREN, S. The Economic and Fiscal Contributions of the "Cash for Clunkers" Program-National and State Effects. Center for Automotive research, 2010, CAR Research Memorandum. Dostupné: <http://www.cargroup.org/pdfs/Cash_for_Clunkers_Report.pdf>

[10] DARGAY, J., GATELY, D. Income's effect on car and vehicle ownership worldwide: 1960-2015. Transportation Research, 1998, Research Report 97-33 Dostupné: $<$ http://econ.as.nyu.edu/docs/IO/9382/RR97-33.PDF>.

[11] DE JONG, G., FOX, J., PIETERS, M., DALY, A.J., SMITH, R. A comparison of car ownership models. Transport Reviews [online]. 2004 .Vol. 27, No. 1, pp. 51-67.

[12] European Comission : Environment [online]. 4.6.2010 [cit. 2011-03-09]. Transport \& Environment. Dostupné: <http://ec.europa.eu/environment/air/transport/road.htm>.

[13] GRRENSPAN, A., COHEN, D. Motor Vehicle Stocks, Scrappage, and Sales, Board of Governors of the Federal Reserve System, 1996, Finance and Economics Discussion Series : Paper No. 96-40 .

[14] HAHN, R., W. An economic analysis of scrappage. Journal of economics, 1995, Vol. 26, No. 2, pp. $222-242$.

[15] INGRAM, G. K., LIU, Z. Motorization and Road Provision in Countries and Cities. World Bank, 1997, Policy Research Working Paper No. 1842. Dostupné:

$<$ http://ideas.repec.org/p/wbk/wbrwps/1842.html>

[16] KOBOS, P. H., ERICKSON, J. D., DRENNEN, T., E. Scenario analysis of Chinese passenger vehicle growth. Contemporary Economic Policy, 2003,, Vol 21, No. 2, pp 200-217.

[17] LEE, H., KANG, H. H. The Study of Brazilian Automobile Demand, In Decision Sciences Institute Annual Meeting Procreedings 2008. Atlanta, Georgia : DSI, 2008 
Dostupné: < http://www.decisionsciences.org/Proceedings/DSI2008/docs/1438905.pdf $>$.

[18] LI, S., LINN, J., SPILLER, E. Evaluating “Cash for Clunkers”: Program Effects on Auto Sales, Jobs, and the Environment. Resources for the Future, 2010, Discussion paper 10-39. Dostupné: <http://www.rff.org/documents/RFF-DP-10-39.pdf>

[19] LICANDRO, O., SAMPAYO, A., R. The Effects of Replacement Schemes on Car Sales: The Spanish Case. Investigaciones Económicas, 2006, Vol 30, No. 2, pp239282.

[20] MIAN, Atif; SUFI, Amir. The Effects of Fiscal Stimuls : Evidence from the 2009 'Cash for Clunkers' Program. NBER, 2010, Working Paper No. 16351. Dostupné: $<$ http://mba.americaeconomia.com/system/files/mian_sufi.pdf $>$.

[21] PARKS, W. Determinants of Scrapping Rates for Postwar Vintage Automobiles. Econometrica, 1977, Vol. 45, No. 5, pp. 1099-1115.

[22] PSP. 2009. Návrh zákona o podpoře hospodářského růstu a soc.stability. [Online][cit. 19. 4 2011.] Dostupné: <http://www.psp.cz/sqw/historie.sqw?o=5\&t=743\&sp=1>.

[23] SANDSTRÖM, Mikael. Car age, taxation, scrappage premiums and the ELV Directive. The Research Institute of Industrial Economics. 2003, Working Paper No. 591

[24] TANNER , J. C. Long-Term Forecasting of Vehicle Ownership and Road Traffic. Journal of the Royal Statistical Society, 1978, Vol 141, No. 1, pp 14-63.

[25] TRAIN, K. Qualitative Choice Analysis : Theory, Econometrics, and an Application to Automobile Demand [online]. Cambridge : The MIT Press, 1996 [cit. 2010-11-14]. Dostupné: <http://elsa.berkeley.edu/books/choice.html>. ISBN 0-262-20055-4.

[26] WALKER, P. Determinants of Auto Scrappage. The Review of Economics and Statistics. 1968, Vol. 50, No. 4, pp. 503-506. Dostupné:

$<$ http://www.jstor.org/stable/1926820>.

[27] WHELAN, G. Modelling car ownership in Great Britain. Transportation Research, 2007, Vol 41, pp 205-219.

[28] WOLFF, P. The demand for passenger cars in United States. Econometrica, 1938, vol. 6, No. 2, pp. 113-129.

[29] Zákon č. 185/2001 Sb. : o odpadech a o změně některých dalších zákonů ve znění pozdějších předpisů. [online]. [cit. 2011-05-01].

Výsledky uvedené v příspěvku jsou součástí výzkumného záměru VZ MSM 6215648904 „Česká ekonomika v procesech integrace a globalizace a vývoj agrárního sektoru a sektoru služeb v nových podmínkách evropského integrovaného trhu“, tematického okruhu 01 „Makroekonomická a mikroekonomická výkonnost české ekonomiky a hospodářskopolitická opatření vlády ČR v podmínkách evropského integrovaného trhu“. Uvedený záměr je řešen na PEF MZLU v Brně za finanční podpory ze státních prostředků prostřednictvím MŠMT.

Příspěvek vznikl rovněž za podpory projektu IGA 1/2011.

\title{
JEL L62, H2, H3
}

\author{
Bc. Marek Litzman \\ Ing. Luděk Kouba, Ph.D. \\ Ing. Jitka Dušková, Ph.D.
}


Ústav ekonomie PEF

Mendelova Univerzita v Brně

Zemědělská 1, 61300 Brno

xlitzman@node.mendelu.cz

kouba@mendelu.cz

duskova@mendelu.cz 